\title{
Paradoxical Normativities in Brunei Darussalam and Malaysia
}

\author{
Islamic Law and the ASEAN Human Rights Declaration
}

\begin{abstract}
Brunei and Malaysia are promoting the ASEAN Human Rights Declaration but enforce a brand of Islamic law that systematically violates it. The paradoxical ways in which policymakers are navigating between the two, and the empirical realities of Islamic governance, impede the project of a transdoctrinal justification of human rights.
\end{abstract}

KEYWORDS: Islamic governance, human rights, ASEAN, Brunei Darussalam, Malaysia

\section{INTRODUCTION}

The legal landscapes of Malaysia and Brunei Darussalam (henceforth Brunei) have undergone unprecedented transformations toward an increasing enforcement of Islamic law in recent years, accompanied by a passionate demonization of religious pluralism among both countries' political leaders and governmental clergy. Most controversially, codified Shariah law in Brunei and Malaysia now also incorporates elements of Islamic criminal law, while interpretations of Islam that differ from the authorities' official doctrines are systematically outlawed as "deviant" (sesat). Simultaneously, these same governments that are restricting civil liberties in the name of divine legislation expressed their commitment to religious freedom and nondiscrimination by signing the ASEAN Human Rights Declaration (AHRD) in 2012. Depending on situational contexts, their political leaders are-in remarkably

Dr. Dominik M. Müller is a post-doctoral fellow in political anthropology at the Cluster of Excellence "Normative Orders" at the Goethe University of Frankfurt, Germany, and was a visiting scholar at the Asian Studies Centre at St Antony's College, University of Oxford, while preparing the final version of this article. He is the author of Islam, Politics and Youth in Malaysia: The Pop-Islamist Reinvention of PAS (Routledge, 20I4). Email: <dominikmueller@em.uni-frankfurt.de>.

Asian Survey, Vol. 56, Number 3, pp. 4I5-44I. ISSN ooo4-4687, electronic ISSN 1533-838X. (C) 2016 by The Regents of the University of California. All rights reserved. Please direct all requests for permission to photocopy or reproduce article content through the University of California Press's Reprints and Permissions web page, http://www.ucpress.edu/journals.php? $\mathrm{p}=$ reprints. DOI: I0.I525/AS.20I6.56.3.4I5. 
similar ways-using flexible strategies to position themselves in between human rights and Shariah law. Their arguments range from the claim that human rights are essentially "Islamic" and fully compatible with Shariah law, to the accusation that human rights are Western, "man-made" inventions which are incompatible with God's legislative commandments, or must be subordinated to them. In the process of navigating between these two normative frames of reference, "human rights" is transformed into a polysemic signifier: one with multiple meanings. Beyond rhetoric and symbolic regional diplomacy, however, an antipluralistic brand of Islam that systematically violates the fundamental right to religious freedom is characterizing the sanction-based standardization of Shariah law in both countries.

This article will first outline some conceptual considerations on the plurality of justificatory grounds for human rights, before sketching the AHRD and its protection of the freedom of thought, conscience, and religion. It will then explore the dynamics of Shariah politics in Brunei and Malaysia, and illustrate how Islamic policymakers are connecting the languages of Islamic law and human rights in paradoxical ways. Finally, the article concludes that despite some rhetorical hybridization on the surface, the empirical realities of Islamic governance in contemporary Brunei and Malaysia are hardly reconcilable with the ideal-theoretical project of transdoctrinal justifications for human rights.

\section{CONCEPTUAL CONSIDERATIONS: NORMATIVE PLURALITY AND THE JUSTIFICATION OF HUMAN RIGHTS}

In the face of criticisms of the Western roots, secular underpinnings, and political exploitation of supposedly "universal" human rights, arguments for acknowledging the possibility of multiple justificatory grounds, or a plural justification of human rights, have gained prominence across disciplinary boundaries. Their proponents disagree with the assumption that human rights norms can only be justified based on one "tradition-independent moral standard," ${ }^{1}$ but they also refuse to abandon human rights on culturalrelativist grounds. Instead, they argue that even adherents of differing, possibly even incompatible normative traditions may finally endorse the same

I. David Little, "Rethinking Human Rights: A Review Essay on Religion, Relativism, and Other Matters," Journal of Religious Ethics 27, no. I (Spring 1999): I5I-I77, p. I64. 
conception of universally acceptable human rights, albeit for different, yet internally well-supported reasons. ${ }^{2}$ If adherents of any given normative tradition reasonably believe that universal human rights are supported by their tradition, this "overlapping consensus" 3 could help bridge cultural divides between groups that commonly appear separated by contrasting doctrines and premises.

Put differently, a unifying conclusion — universal human rights—could be derived from mutually incompatible premises. Tore Lindholm refers to the struggle of liberal Muslim thinkers for a brand of Islam that is compatible with the Universal Declaration of Human Rights (UDHR) - including the right to religious freedom, equality before the law, and nondiscriminationto illustrate the empirical relevance of this argument. ${ }^{4}$ Leaving aside philosophical controversies about the argument's messy logical implications, this article will ask: How does the call for a transdoctrinal, plural justification and subsequent universal acceptance of human rights resonate with the empirical realities of Islamic governance in Southeast Asia, particularly in Brunei and Malaysia? Can we observe tendencies toward an endorsement of the freedom of thought, conscience, and religion, nondiscrimination, and equality before the law, as it is stipulated by the UDHR and AHRD? Are compatible conclusions derived from two coexisting normative systems? And how is the way Islamic policymakers are positioning themselves between Shariah law and human rights embedded in both countries' wider political landscape?

The fact that human existence is typically shaped by the complexity of multiple coexisting normativities, or "legal pluralism," is now commonplace among scholars of socio-legal studies. Although the empirical diagnosis of

2. Tore Lindholm, "The Cross-Cultural Legitimacy of Universal Human Rights: Plural Justification across Normative Divides," in Cultural Human Rights, ed. Martin Scheinin and Francesco Francioni, I7-39 (London: Martinus Nijhoff, 2008), p. I7; see also Abdullahi A. An-Na'im, "Towards a Cross-Cultural Approach to Defining International Standards of Human Rights: The Meaning of Cruel, Inhuman, or Degrading Treatment or Punishment," in Human Rights in CrossCultural Perspective: A Quest for Consensus, ed. Abdullahi A. An-Na'im, I9-43 (Philadelphia: University of Pennsylvania Press, 1992); John Witte and Johan D. van der Vyer (eds.), Religious Human Rights in Global Perspective: Religious Perspectives (The Hague: Martinus Nijhoff, 1996), 2 vols.

3. Abdullahi A. An-Na'im, "The Cultural Mediation of Human Rights: the Al-Arqam Case in Malaysia," in The East Asian Challenge for Human Rights, ed. Joanne R. Bauer and Daniel A. Beil, I47-I68 (Cambridge: Cambridge University Press, 1999), p. 167; Charles Taylor, "Conditions of an Unforced Consensus on Human Rights," in East Asian Challenge, pp. 27-60.

4. Lindholm, "Cross-Cultural Legitimacy," p. 27. 
legal pluralism has almost become a cliché after decades of extensive debates, ${ }^{5}$ it is nevertheless an important premise, particularly as Islamic normativity is often conceived in static, one-dimensional terms. A second premise refers to the functional dimension of law as a discursive resource for social actors (institutional and noninstitutional, powerful and less powerful, dominating and resisting) to reach certain objectives or justify actions, claims, and decisions. Policymakers, including Islamic ones, may therefore flexibly refer to one or more — even presumably incompatible—normativities, depending on their political interests and specific situational requirements.

Franz von Benda-Beckmann has distinguished five different ways in which social actors flexibly refer to coexisting normativities to pursue their interests. Although his typology describes a specific empirical context, namely adat (customary rules) and Islamic norms in Indonesia, it can insightfully be applied to other settings. Competing actors, or even one and the same person, may (I) argue within the boundaries of only one normativity, (2) mobilize two normativities against each other and portray them as incompatible (or, alternatively, as superior/inferior), (3) combine both normativities while using them selectively (e.g. by arguing that each normative order covers different aspects, and that elements of both can be applied simultaneously wherever appropriate), (4) claim that there is no difference, as both are actually "the same," despite being aware of differences between the two, or (5) creatively transform or compound elements of coexisting normativities and create new hybrid forms. ${ }^{6}$ Keeping these diverse strategies in mind, this article will investigate how the governments of Brunei and Malaysia are navigating between Islamic law and human rights. But first, ASEAN's emerging regional framework for protecting human rights, and particularly the right to freedom of thought, conscience, and religion, needs to be sketched.

5. John Griffiths, "What is Legal Pluralism?” Journal of Legal Pluralism I9 (1986), pp. I-47; Franz von Benda-Beckmann, Rechtspluralismus in Malawi: Geschichtliche Entwicklung und Heutige Problematik [Legal Pluralism in Malawi: Historical Development and Contemporary Problems] (München: Weltforum, 1970); Fernanda Pirie, The Anthropology of Law (Oxford: Oxford University Press, 2013), pp. $38 \mathrm{ff}$.

6. Franz von Benda-Beckmann, "Who's Afraid of Legal Pluralism?” Journal of Legal Pluralism and Unofficial Law 34, no. 47 (2002): 37-82, pp. 69-70. 


\section{THE ASEAN HUMAN RIGHTS DECLARATION AND ITS PROTECTION OF RELIGIOUS PLURALISM}

Political controversies about religion are highly salient in Southeast Asia, as religious diversity is a characteristic feature of most ASEAN countries, some of which have decades-long histories of religious, or to some extent religiously framed, violent conflicts and social tensions. Accommodating religious plurality is thus a crucial challenge for creating a Southeast Asia that is "prosperous and peaceful," as envisioned by the ASEAN Declaration of 1967 . The question of how religious diversity should be dealt with, and under which normative parameters it should be organized, is at the heart of respective debates. The ASEAN governments' strategies for regulating their domestic religious marketplaces are as diverse as the region itself. ${ }^{7}$

Originally consisting of Indonesia, Malaysia, the Philippines, Thailand, and Singapore, ASEAN was founded in 1967 with the purpose of creating political stability and economic progress in the region. Forty years later, now comprising IO states, including also Brunei, Cambodia, Laos, Myanmar, and Vietnam, ASEAN received a solid legal foundation with the ASEAN Charter of 2007. Intense negotiations were held about whether the charter should include articles on human rights—-talks made particularly difficult by the participation of states notorious for human rights violations and governments that had long questioned individual human rights on communitarian or cultural-relativist grounds. Nonetheless, the ASEAN Charter finally expressed its member states' responsibility to protect "human rights and fundamental freedoms," and announced the establishment of an ASEAN human rights body. ${ }^{8}$ The ASEAN Intergovernmental Commission on Human Rights was formed in 2009, when it began drafting an ASEAN human rights document. Three years later, in November 20I2, the ASEAN Human Rights Declaration was presented and adopted unanimously by all to member states. Despite well-justified criticisms that the AHRD is "a pale shadow of what it could have been,"” the declaration

7. For an ASEAN-wide study to which the author contributed, see Human Rights Resource Centre, Keeping the Faith: A Study of Freedom of Thought, Conscience and Religion in ASEAN, ed. Jaclyn Neo (Jakarta: HRRC, 20I5).

8. Preamble; Article I(7); 2(i).

9. Deborah Basham-Jones, “Asean's Intergovernmental Commission on Human Rights: A Pale Shadow of What it Could Have Been," Asia-Pacific Journal on Human Rights and the Law I3, no. 2 (20I2), pp. I-26. 
presents an institutionalized regional commitment to clearly defined human rights that is unprecedented.

Although many details of the AHRD deserve attention, for the purposes of this article it is sufficient to note that the declaration unambiguously protects religious freedom and obliges governments to eliminate any form of religious discrimination. More precisely, Article 22 states that "every person has the right to freedom of thought, conscience and religion. All forms of intolerance, discrimination and incitement of hatred based on religion and beliefs shall be eliminated." Article 23 adds that "every person has the right to freedom of opinion and expression." The AHRD also affirms equality before the law without distinction of any kind, such as "religion," "gender," and "political or other opinion" (Articles I, 2). Finally, according to Article 6, it is "the primary responsibility of all ASEAN member states to promote and protect all human rights" that are stated in the AHRD.

To be sure, the AHRD also stipulates noteworthy limitations, which still reflect the old "ASEAN way"10 of emphasizing national sovereignty and restricting the validity of human rights with reference to cultural particularities and collectivism. Article 6 states that "the enjoyment of human rights ... must be balanced with the performance of corresponding duties" toward "the community and the society where one lives." Accordingly, although these rights are presented as "universal" and "indivisible," "the exercise of human rights... shall be subject... [to] limitations" pertaining to, among other points, the requirements of "national security, public order," and "public morality" (Articles 7, 8). Furthermore, the backdoor of cultural relativism is left half-open by stating that "the realisation of human rights must be considered in the regional and national context bearing in mind different political, economic, legal, social, cultural, historical and religious backgrounds" (Article 7, emphasis added). In the cases of Brunei and Malaysia, it is precisely the latter point that undermines the declaration's proclaimed protection of religious freedom, as the following sections will demonstrate.

Io. Donald K. Emmerson, "Critical Terms: Security, Democracy, and Regionalism in Southeast Asia," in Hard Choices: Security, Democracy and Regionalism in Southeast Asia, ed. Donald K. Emmerson, 3-58 (Stanford, CA: Shorenstein APARC, 2008), p. 23. 


\section{ISLAMIC GOVERNANCE IN BRUNEI}

The sultanate of Brunei-located on the island of Borneo, with a population of 420,000-is the only ASEAN country that has unambiguously defined itself as a nonsecular "Islamic state"11 since its Declaration of Independence from Britain in 1984. Beyond its shores, Brunei appears mainly in the yellow press, which occasionally carries entertainment-oriented reports about the sultan (once known as the "richest man in the world") and his extravagant properties, or colorful royal weddings and rituals. Even in neighboring countries, there has long been little interest in, or substantial knowledge of, Brunei's domestic affairs. This changed when the sultan announced a farreaching enforcement of Islamic criminal law in 20I3, the Syariah Penal Code Order 20I3 (Perintah Kanun Hukuman Syariah 20I3, henceforth SPCO 2013), followed by waves of protest from international human rights organizations and applause from Islamist actors in neighboring countries. Before describing this legal reform in more detail, some contextual information must be provided.

Brunei is an Islamic monarchy, governed by a sultan with absolute executive powers. The present sultan, Hassanal Bolkiah (in office since 1967, crowned in 1968), is prime minister, minister of finance, minister of defense, minister of foreign affairs and trade, and head of Islam (or caliph, i.e. "God's vice-regent on earth"12). There is no parliament, and there are no general elections. The Legislative Council, which was suspended in 1984, was re-established in 2004. It has no substantial legislative powers and plays only an advisory role; the sultan appoints most council members. Accordingly, Brunei's political system is a unique polity in Southeast Asia, as it derives its legitimacy exclusively from a reciprocal patron-client relationship between an unelected "caring monarch" and his subjects.

Since a traumatic antimonarchical rebellion in 1962 (put down with British help within two weeks), emergency laws, a strict legal regime, and highly powerful state institutions have been used to minimize political dissent. After five decades of systematically depoliticizing the population, there is no

II. Abdul Latif Ibrahim, Issues in Brunei Studies (Bandar Seri Begawan: Akademi Pengajian Brunei, 2003), p. 197; Abdul Latif Ibrahim, Melayu Islam Beraja: Suatu Pemahaman [Malay Islamic Monarchy: An Understanding] (Bandar Seri Begawan Pentagram, 20I3), pp. 5I-52.

I2. Constitution of Brunei Darussalam, Part II, Article 2; Ibrahim, Issues in Brunei Studies, p. 205; Mohd. Zain Serudin, The Malay Islamic Monarchy: A Closer Understanding (Bandar Seri Begawan: MTMIB, 2013), p. 23. 
opposition group left, neither organized as a political party nor as civil society actors. The mediascape, including cyberspace, is under sophisticated control. Brunei's didactic news media serve to promulgate the government's positions, including its religious policies. Political stability is strengthened by exceptional living standards. Brunei ranks 3Ist in the Human Development Index 20I5; it is the world's highest-ranked Muslim-majority country. Large oil and gas resources have enabled the creation of a generous welfare state. The sultan enjoys the image of a benevolent leader, which is also intensely fostered by the state-controlled media. Citizens benefit from extraordinary social security, including zero income tax, free health care, free education, and subsidized housing. The sultan annually gives thousands of personal gifts (kurnia peribadi) on the occasion of Hari Raya Aidil Fitri, the end of the fasting month, to citizens, who can send their wishes to the palace or hand over envelopes during his frequent public appearances.

The ruling family's official genealogy, dating back to the fourteenth century, presents Sultan Hassanal Bokiah as Brunei's 29th Muslim ruler and a descendant of Prophet Muhammad. The population's majority are ethnic Malay (65.7\%), and $78.8 \%$ of Brunei is Muslim. The government portrays the sultanate's six-century history of absolute rule as a distinctly Malay cultural tradition that must be protected from dangerous foreign influences. These historical, religious, and ethnic dimensions of justifying the ruling order are enshrined in an official "state ideology" called Melayu Islam Beraja (Malay Islamic Monarchy), or MIB.

MIB was announced in 1984, when the sultan declared that Brunei shall "forever be a Malay Islamic Monarchy." Described interchangeably as a "national philosophy," "concept of the nation," and "ideology," MIB rests on three pillars defining the core of prescribed national identity: Melayu (Malayness), Islam, and Beraja (Monarchy). In this triangle, the Islamic aspect is considered supreme. ${ }^{13}$ Critical scholars, none of whom is a Bruneian citizen, have deconstructed MIB as a twentieth-century nation-building project, an "ideological construct" that has been "exploited" for self-legitimization. ${ }^{14}$

I3. Ibrahim, Issues in Brunei Studies, p. 206; Ibrahim, Melayu Islam Beraja, p. xxxiii; Zain Serudin, Melayu Islam Beraja: Suatu Pendekatan [Malay Islamic Monarchy: An Approach] (Bandar Seri Begawan: Dewan Bahasa dan Pustaka, 1996), p. xi.

I4. Tsung Hang Tey, "Brunei: Entrenching an Absolute Monarchy," in Constitutionalism in Southeast Asia, vol. 2, ed. Clauspeter Hill and Jörg Menzel, 7-35 (Singapore: Konrad Adenauer Stiftung, 2008), p. 34; G. Braighlinn, Ideological Innovation under Monarchy: Aspects of Legitimation 
Bruneian scholars respond that notwithstanding the term's recent invention, it appropriately describes the authentic nature of the sultanate's centuries-old tradition. ${ }^{15} \mathrm{MIB}$ serves as a sacrosanct political and cultural imperative. On all levels of the education sector, compulsory MIB courses are taught, and laudatory reference to MIB is a discursively naturalized element of official public life-it is a general norm, practiced by and expected from most citizens and institutions, to regularly stress the importance of the national ideology. News media serve to re-actualize this norm on a daily basis. Government institutions frequently organize events to propagate MIB, whereas non-governmental actors, including commercial companies, habitually present their work as a "service to MIB" and thereby express their commitment to "good citizenship," as the government defines and expects it. Brunei society is typically described as "apathetic," "depoliticized," and "contented, even docile."16 Such notions express an undeniable tendency, although they blend out forms of dissent and refusal of obedience to the government's official truth claims that still exist beyond the surface. ${ }^{17}$

Brunei's constitutional religion is Sunni Islam of the Shafi'i legal school. Religious minorities include Christians, Buddhists, and smaller numbers of Hindus, Sikhs, Taoists, Baha'is, and animists. The government seeks to ensure "national harmony" under Muslim Malay supremacy. It celebrates "cultural diversity," with ethnic minorities staging cultural performances on festive occasions. Plurality, however, does not mean pluralism. In recent years the sultan has repeatedly condemned "religious pluralism" and "liberal Islam" as "deviationism" that "will never be related to Brunei." ${ }^{18}$ Accordingly, MIB considers

Activity in Contemporary Brunei (Amsterdam: VU Press, 1991); Geoffrey C. Gunn, Language, Power and Ideology in Brunei Darussalam (Athens: Ohio University Press, 1997); Sven Schottmann, "Melayu Islam Beraja: The Politics of Legitimisation in a Malay Islamic Monarchy," Review of Indonesian and Malay Affairs 40, no. 2 (2006), pp. III-39.

I5. Serudin, Melayu Islam Beraja, p. 45; Ibrahim, Issues in Brunei Studies, p. 200.

I6. A. V. M. Horton, "Brunei National Democratic Party," in Southeast Asia: A Historical Encyclopedia, From Angkor Wat to East Timor, ed. Ooi Keat Gin (Santa Barbara: ABC-CLIO, 2004), p. 274; Andrew Tan, "Brunei Security Perspectives," in Security Perspectives of the Malay Archipelago, ed. Andrew Tan, 87-IIo (Cheltenham: Edward Elgar, 2004), p. 99; Mohamad Yusop, "Brunei Darussalam: Towards a New Era," Southeast Asian Affairs 2007 (Singapore: ISEAS, 2007), pp. I03-I3.

I7. Regrettably, such forms of non-compliance have received very little, if any, scholarly attention in recent years. For an anthropological account, see Dominik M. Müller, "Sharia Law and the Politics of 'Faith Control' in Brunei Darussalam: Dynamics of Socio-Legal Change in a Southeast Asian Sultanate," Internationales Asienforum 46, no. 3/4 (2015), pp. 313-45.

I8. "Call to Shun Deviant Beliefs, Follow Prophet's Teachings," Brunei Direct (Bandar Seri Begawan, Brunei Darusslam), November 15, 2012; "Muslims Urged Not to be Swayed by Guises of Islamic Liberalism," Brunei Times, February 9, 20I3. 
loyal non-Muslims and non-Malays "protected minorities," but excludes them from desirable national identity.

While non-Muslim religions can be practiced, with restrictions, interpretations of Islam other than MIB-style Sunni Shafi'i are even further restricted. Historically, Brunei was ahead of the regional trend of outlawing "deviant sects," a phenomenon that is presently causing great concern in Malaysia (ajaran sesat) and Indonesia (aliran sesat). During the tenure of State Mufti (the country's highest-ranking Islamic official and interpreter of Islamic Law) Ismail Omar Abdul Aziz (I962-93), Brunei started codifying a list of "deviant" groups, nowadays including e.g. the Ahmadiyyah (banned I970), Baha'i (banned 1970), Tarekat Mufarridiyah (banned 1979), Al-Arqam (banned I99I), Shia Islam, and the teachings of certain individuals. ${ }^{19}$ Al-Arqam, a revivalist orthodox Islamic movement which gained support among educated elites, was banned three years before it was more prominently outlawed in its country of origin, Malaysia, in I994. In addition to being viewed as a political threat, members of the Arqam community believed that its leader, Abuya Ashaari Mohammad (who died in 20Io), was blessed by Allah with various supernatural powers and was able to communicate with the Prophet Muhammad through another deceased intermediary, Syeikh Muhammad As-Suhaimi, among other theologically controversial claims. Brunei's "faith/doctrine control" (kawalan aqidah) policies are executed by religious enforcement agencies, police, and intelligence services. There are 24-hour "hotlines" for citizens to report "deviant" individuals. Institutions responsible for the definition, control, and administration of Islam include the Ministry of Religious Affairs, State Mufti Department, Religious Council (the "chief authority" in "all matters relating to religion" ${ }^{20}$ ), the Religious Council's Legal Committee (headed by the state mufti, whose fatwas are legally binding), Syariah [Shariah] Affairs Department, Faith Control Section, and several sub-institutions.

In contrast to other Muslim-majority countries, Brunei's Islamic policies "are discussed internally and... introduced slowly and quietly. Open religious polemics and debates have never taken place." ${ }^{21}$ Without ever being openly questioned by organized secular or Islamist critics, the government's

19. Müller, "Sharia Law," p. 327.

20. Religious Council and Kadis Courts Act, Article 38.

21. Iik Arifin Mansurnoor, 2002, "Islam in Brunei Darussalam and Global Islam: An Analysis of their Interaction," in Islam in the Era of Globalization: Muslim Attitudes towards Modernity and Identity, ed. Johan Meuleman, 7I-98 (London: RoutledgeCurzon, 2002), p. 88. 
clergy has established an officialized state interpretation of Islam as an unquestionable Muslim truth, strengthened by systematic indoctrination and the threat of sanctions for transgressions. Contents of Friday prayers are carefully prescribed, and Islamic preachers are required to obtain government licenses. Unlike in Malaysia, no politician or social actor has ever publicly suggested or demanded that Brunei be "secular."

Brunei's Shariah legislation has long been based on a dual legal system, in which Islamic and British-derived laws coexist. Before the colonial era, the monarchy was organized under interrelated Shariah and customary law, codified as Hukum Kanun Brunei (Code of Laws of Brunei) alongside Hukum Resam and Adat Istiadat (Customary Laws). ${ }^{22}$ The British administration paved the way for a more systematic form of Shariah-based governance. Under Indirect Rule, British colonial advisors encouraged a "modern" codification of Islamic law and related institution building, starting in 1912 and continuing throughout the Residency period. ${ }^{23}$ Although most Bruneian scholars perceive colonialism as a secular or "infidel" disturbance of a previously existing "complete" Islamic order ${ }^{24}$ and while colonial Shariah law was indeed largely limited to family law, the British-supported legacy of institutionalization and legalism created the foundation of today's powerful Islamic bureaucracy. ${ }^{25}$

22. An Islamic penal code existed in Brunei prior to the British arrival in I888; see Mahmdud Seadon Othman, Perlaksanaan dan Pentadbiran Undang-Undang Islam di Negara Brunei Darussalam: Satu Tinjauan [Implementation and Administration of Islamic Laws in Brunei Darussalam: A Review] (Bandar Seri Begawan: Dewan Bahasa dan Pustaka, 1996), pp. 99-Ioo. Hudud-based cutting off of thieves' hands, for example, was practiced at least occasionally; see Mahmdud Seadon Othman, Ke Arah Perlaksanaan Undang-Undang Islam di Negara Brunei Darussalam [Towards the Administration of Islamic Laws in Brunei Darussalam] (Bandar Seri Begawan: UBD, 200I), pp. 2ff. Accordingly, the SPCO 2013 is framed as "a continuation" of a law that was first introduced in Brunei in the sixteenth century but "was abruptly halted" by colonialism ("Syariah Penal Code Not New to Brunei," Brunei Times, January I2, 20I4). Other sources, however, describe certain regulations and punishments that have no basis in Islamic teachings.

23. Indirect rule was a colonial strategy and system of government used in large parts of the British Empire in India, Africa, and Southeast Asia, wherein pre-colonial power structures were not entirely destroyed. In colonial Malaya and Brunei, the British retained existing sultanates but limited the rulers' authority to Islamic affairs and Malay customs, and "assisted" their work through colonial "advisors." This approach was considered easier, less expensive, and more effective. Brunei was given the status of a British Protectorate in I888, and the first locally stationed British resident, Malcom S. H. McArthur, was appointed in 1906 as a colonial manager and advisor to the sultan.

24. Ibrahim, Issues in Brunei Studies, p. IOI; Othman, Ke Arah Perlaksanaan, pp. 2ff.

25. Iik Arifin Mansurnoor, "Formulating and Implementing a Shari'a-Guided Legal System in Brunei Darussalam: Opportunity and Challenge," Sosiohumanika I, no. 2 (2009), pp. 219-48; Müller, "Sharia Law," p. 32 I. 
After independence, the Shariah sector was further empowered, fueled by transnational Islamic revivalism, ideological developments within Brunei's Islamic bureaucracy, ${ }^{26}$ power-political considerations, and the growing piety of the aging sultan, Hassanal Bokiah. Since 1990, non-Shariah laws have been systematically reviewed to ensure that they do not conflict with Islamic norms. ${ }^{27}$ Prior to 20I4, Shariah law applied exclusively to Muslims, whereas non-Shariah law was applicable to all citizens. This dual system has been altered by the SPCO 2013, which includes certain provisions for nonMuslims, including punishments such as imprisonment, and even the death penalty (e.g. for insulting Prophet Muhammad). The government has defined its new legal system as "hybrid," ${ }^{28}$ and claims that enforcing the SPCO 2013 will lead to a complete implementation of Islamic law. It will be enacted over three stages. The first started on May I, 20I4, and includes 55 "general offences" ( $\left.t a^{\prime} z i r\right)$ that can be punished with monetary fines and imprisonment. Heavier punishments (hududlqisas) such as the death penalty by stoning and the amputation of limbs will gradually be implemented in the second and third phase, which will take effect $\mathrm{I} 2$ and 24 months after the Syariah Courts Criminal Procedure Code (CPC), now in draft form, is gazetted. In addition, 209 amendments were made to Brunei's earlier Islamic legislation. In January 20I6, the sultan sharply criticized the Ministry of Religious Affairs for not having finalized the CPC yet. Minister of Religious Affairs Awang Badaruddin (who was just recently appointed) publicly apologized and pointed to the project's challenging organizational complexities ("something totally new"). He declared June 2016 the target for gazetting the CPC and June 2017 for the SPCO's phase $2 .^{29}$ The former minister, Mohammad Abd. Rahman, had been removed from his office following a cabinet reshuffle in October 2015 .

When international observers became aware of the reform in early 20I4, the sultanate received unprecedented attention. American celebrities staged demonstrations in front of a luxurious hotel owned by the sultan in

26. For a more detailed account of this process, see Müller, "Sharia Law."

27. "Laws to Be Brought in Line with Islam," Brunei Darussalam Newsletter 60 (September 1990), p. I.

28. "Unique Hybrid Legal System Mooted," Brunei Times (Bandar Seri Begawan, Brunei), January $5,2012$.

29. "Gov't Targets Syariah CPC Completion by June," Brunei Times, February 28, 2016; "Buat bersungguh-sungguh" [Act Earnestly], Media Permata (Gadong, Brunei), February 29, 2016. 
Beverly Hills, California, that had long been popular among actors, to protest the "barbaric" human rights violations that Brunei's new law allegedly implied. As a comprehensive description would go beyond the scope of this article, only some of the most controversial provisions of the law will be mentioned:

- The SPCO 2013 stipulates that any person who insults the Prophet Muhammad and refuses to repent can be sentenced to death, or alternatively to 30 years' imprisonment and caning. ${ }^{30}$

- Anyone who insults or “makes fun of” Islamic teachings, practices, laws, or the State Mufti's fatwas can be imprisoned for three years. ${ }^{31}$

- Contempt of members of the Shariah administration is punishable by up to two years in prison. ${ }^{32}$

- The public dissemination of beliefs or practices that are considered contrary to Islamic law, or exposing Muslims to ceremonies, acts or doctrines that contradict Islamic law, is punishable by up to five years in prison. ${ }^{33}$

- Muslims who declare themselves God or prophet, and Muslims who deny the validity of the hadith (reports describing the sayings and actions of the Prophet and his companions, which in Islamic jurisprudence traditionally serve as a source of Shariah law) can be punished by death. ${ }^{34}$

- Muslims who worship "any person, place, nature or any object, thing or animal in any manner" contrary to Islamic law (e.g. by believing that objects or animals possess certain powers, "increase wealth," "heal diseases" or "bring good luck") can be imprisoned and forced to undergo religious "counseling." ${ }^{35}$

- Not attending Friday prayers is a criminal offense. ${ }^{36}$

- Islamic preaching and teaching without a permit can be punished by up to two years' imprisonment. ${ }^{37}$

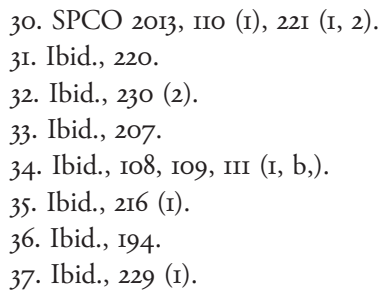


- Extramarital sex (zina) is punishable for Muslims by stoning to death, whipping, or, if certain procedural conditions are not met, up to seven years' imprisonment. ${ }^{38}$

- Pregnancy or childbirth out of wedlock can be punished by two years in prison. ${ }^{39}$

- Muslims and non-Muslims can receive the death penalty for homosexual intercourse, or intercourse "against the order of nature that is through the anus." 40

- Muslim apostates can also be punished with death by stoning, or up to 30 years' imprisonment and whipping, if they refuse to repent. ${ }^{41}$

- Non-Muslims are not allowed to proselytize and cannot disseminate religious literature. Teaching non-Muslim religions or alternative interpretations of Islam in schools is forbidden.

Notably, several of these offenses were also forbidden before the legal reform. However, the punishments have been drastically increased, and additional provisions have been added. The government strongly emphasizes the procedural principle of doubt ${ }^{42}$ on the part of the accused, which makes it difficult to convict persons who refuse to make voluntary confessions, and various mechanisms for repentance and the lifting of sentences. It remains to be seen how the SPCO will finally be enacted in practice. At present, judges are being trained, and the Sultan Sharif Ali Islamic University has introduced a new diploma called Shariah Criminal Justice System for law enforcement officers and students, in addition to a B.A. program with the same title.

The legal reform's announcement resulted in popular uncertainties that were highly unusual by Bruneian standards. As a reaction, the government held numerous events across the country-attended by "over 40,00o people," Io \% of the population - to educate them about the new law. ${ }^{43}$ Initially, some Bruneians expressed concerns anonymously in online discussion forums and the comments section of online newspapers. However, when one

38. Ibid., 68 (I), 69 (I, a, b), 69 (2, a).

39. Ibid., 94 (I, a).

40. Ibid., 82 (I, 2).

4I. Ibid., II2 (I); “Apostasy Punishable by Death,” Brunei Times, April 2, 2013.

42. On the importance of the principle of doubt (or the "art not to punish") in the legal theory and history of Islamic criminal law, see Intisar A. Rabb, Doubt in Islamic Law: A History of Legal Maxims, Interpretation, and Islamic Criminal Law (Cambridge: Cambridge University Press, 20I6). 43. "Over 40,0oo People Briefed on Syariah," Brunei Times, May I, 2014. 
citizen used his real name in 2013, the government used the case to make an example.

Shortly after the sultan first announced the legal reform, a reader's letter questioning whether stoning to death and flogging were obligatory in Islam, as the Qur'an made no such prescription, was sent to a local newspaper. ${ }^{44}$ The author, clearly a committed Muslim, argued that the maximum punishment for adultery should be Ioo lashes. Strangely enough, the letter was printed, but the authorities reacted immediately. First, the Ministry of Religious Affairs published a response article explaining why enforcing such penalties was unquestionably obligatory. The article ended with an "invitation" to the author to visit the Ministry for further "explanations." Shortly afterwards, the state mufti publicly warned of a deviationist "anti-hadith movement" that denied Prophetic traditions and referred to the Qur'an without theological knowledge. ${ }^{45}$

While visiting Bruneian students in New Zealand the same week, the sultan condemned the supposed "anti-hadith-movement" that was "secretly desecrating the Islamic laws." 46 The mufti's following Friday prayer sermon warned of "orientalist" and "liberalist" ideas that were spread by ideological descendants of a "pre-Islamic tribe," the Khawarij, that vehemently opposed the Shariah laws. The letter's author was finally sued for heresy, and "given an explanation by the religious authority ... with the cooperation of the Internal Security Department," Brunei's domestic intelligence service. ${ }^{47}$ The case was settled after he publicly repented at a Shariah Court, widely covered by statecontrolled media. The government's Islamic authorities declared that "the next move would be to help" him "deepen his knowledge of Islam." Although the criminal charges were dropped due to his repentance and there was no other penalty, he apparently "agreed voluntarily" to attend the Islamic authorities' "faith purification counselling" program. Obviously, his right to freedom of thought, conscience, and religion, as stated in the AHRD, was violated in the name of divine normativity.

44. "Should We Resort to Stoning or Flogging" (Opinion), Brunei Times, March I3, 2013.

45. "The Punishment of Stoning for a Muhshan Exists in Islamic Law," Borneo Bulletin (Gadong, Brunei), March 23, 2013; "Apostasy Punishable by Death," Brunei Times, April I, 2013.

46. "Beware of Deviant Groups: Imams," Brunei Times, March 30, 2013.

47. "Confession, Repentance for Questioning Islamic Law," Brunei Times, June 8, 20I3; cf. Müller, "Sharia Law," p. 326. 
Other structural violations of the AHRD are related to the fundamental right to equality before the law. Brunei's legal system ascribes different legal status to Muslims and non-Muslims, and to men and women. For example, only a Muslim can become prime minister, and in village council electionsthe only public elections held in Brunei-all candidates must be Muslims. ${ }^{48}$ Although Brunei's Islamic Family Law Act generally supports equal rights for men and women, the inheritance proportion for Muslim women is half that of men, justified by Islamic sources. Furthermore, in some Shariah Court cases, the testimony of one male witness has the same status as that of two female witnesses. ${ }^{49}$

The Office of the UN High Commissioner for Human Rights has stated that the SPCO 2013 seriously violates international human rights law. In response to such criticisms, Sultan Hassanal Bolkiah argued that his government "uphold[s] human rights with the Al-Quran as our foothold." At ASEAN events, the sultan has emphasized his government's promotion of human rights; ${ }^{51}$ indeed, his government hosted the $3^{\text {th }}$ Meeting of the ASEAN Intergovernmental Commission on Human Rights in Brunei in 20I3. Translated into Benda-Beckmann's typology, the sultan does not argue only within the boundaries of one normativity, nor does he mobilize two normative orders against each other and portray them as incompatible. Instead, he combines both normativities and uses them selectively depending on situational context, while on the level of domestic policies making clear that Islamic law is superior. However, his statements can also be read as suggesting that both normativities are actually the same, thereby "bridging" or "hybridizing" the two.

State Mufti Abdul Aziz Juned, one of Brunei's most powerful law and policymakers, explained in October 2013 that "Islam has its own human rights" which, in contrast to human rights claims "stipulated by humans," would "never change through the times." 52 In his view, the only human rights that are universal are "stated in Syariah law." Unlike the sultan, he emphasized

48. Human Rights Resource Centre, Keeping the Faith, p. 6r.

49. SPCO 20I3, I4I (Ib, c), I48 (Ib, c).

50. "UN Concerned at Broad Application of Death Penalty in Brunei's Revised Penal Code," UN News Center, April II, 20I4; "Laws of Islam Seek Blessings Not Oppression," Borneo Bulletin, November 5, 2013.

5I. "HM Lauds ASEAN Role in Promoting Democracy," Brunei Times, November I2, 20I3; see also "Brunei to Attend Human Rights Meeting," Brunei Times, April 28, 2014.

52. "Syariah Law Not against Human Rights," Borneo Bulletin, October 24, 2013. 
a fundamental difference between "man-made" human rights and Islamic law, and mobilized both normativities against each other while simultaneously claiming that "real" human rights and Shariah law are "the same." Brunei's government has also explicated its hybridized reinterpretation of "human rights" at the UN Human Rights Council, explaining that the SPCO 2013 aims "at providing basic human rights." ${ }^{33}$ Depending on situations and target audiences, however, the emphasis varies. In the following section, it will be shown that although Brunei is in many ways a unique polity in the region, there are some striking similarities with Malaysia's Islamic governance and its leaders' paradoxical approach to human rights.

\section{ISLAMIC GOVERNANCE IN MALAYSIA}

Malaysia is the second ASEAN country where Islam is the state's official religion, as stipulated by Article 3 of the Constitution of 1957. In the precolonial era, Islam had played an important political role, dating back to the Sultanate of Malacca in the fifteenth century. Under colonial rule, the British administration granted far-reaching autonomy to the Malay sultans in matters related to Islam and Malay customary law. Accordingly, Islamic governance has long been integral to "the traditional identity of the polity." ${ }^{4}$

Post-colonial Malaysia is multi-religious and multi-ethnic, with more than one-third of the population being non-Muslim, mainly ethnic Chinese and persons of South Asian origin ("Indians"). The constitution states that ethnic Malays (50-55\% of the population)—privileged as bumiputera ("sons/princes of the soil")—are necessarily Muslims. Two political parties, the leading government party United Malays National Organisation (UMNO), which has ruled Malaysia since Independence in 1957, and the Islamist opposition party, Parti Islam Se-Malaysia (Islamic Party of Malaysia, PAS), have competed for decades over Muslim Malay votes, which are the crucial prerequisite for national political power. Despite Islam's constitutional role, UMNO initially conceptualized Malaysia as a secular state, a position that was consistently

53. UN Human Rights Council (Working Group on the Universal Periodic Review), I9th session, "National Report Submitted in Accordance with Paragraph 5 of the Annex to Human Rights Council Resolution I6/2I [Brunei Darussalam]," April 28-May 9, 20I4, p. 3.

54. Dian A. H. Shah, "Constitutional Arrangements on Religion and Religious Freedom in Malaysia and Indonesia: Furthering or Inhibiting Rights?" Indonesian Journal of International \& Comparative Law I, no. I (January 2014): 260-99, p. 265. 
upheld by the first prime minister, Tunku Abdul Rahman (tenure 19571970). ${ }^{55}$ PAS, in contrast, has rejected the notion of secularism since its formation in 195 I.

UMNO's claim of secularism began to crumble during the tenure of Prime Minister Mahathir Mohamad (in office 198I-2003), which coincided with the increasing local popularity of Islamic revivalism (Malay: kebangkitan Islam), a transnational trend of calling for an all-encompassing Islamization and de-secularization of states and societies, which was accelerated by several developments in the Middle East and North Africa, most prominently the Islamic Revolution of Iran in 1978-79. Mahathir's (pseudo)democratically elected administration integrated Islamist activists and ideas, which led to various Islamization policies and a shift to an Islamic vocabulary in UMNO's political rhetoric, particularly when addressing domestic and international Muslim audiences.

Several new Islamic laws were enforced, with I22 enactments and ordinances across the country's regional states (negeri) until 2005. (Notably, Malaysia's administration of Islamic affairs is federally organized, and each state has its own Shariah bureaucracy and legislation.) While during the colonial and early post-colonial era Malaysia's Shariah law was mainly limited to personal law (e.g. marriage and inheritance), the Mahathir government widened the Shariah sector. It gradually also enforced some elements of Islamic criminal law, albeit to varying degrees in different negeri (federal states). An increasingly influential Islamic bureaucracy organizes the administration of Islamic law. Accordingly, Liow argues that although PAS is commonly portrayed as Malaysia's Islamist force, the once secular-oriented UMNO-led government has become an Islamist actor as well, utilizing the state as a "vehicle of Islamization." ${ }^{56}$ In fact, nowadays no UMNO politician openly argues for secularism.

UMNO's appropriation of Islamist ideology evolved vis-à-vis PAS's oppositional calls for a comprehensive "Islamic" order. By 1982-83, when young, Middle East-trained Islamist reformists took over PAS's leadership, a process began that became known as the PAS-UMNO "Islamization race." ${ }^{7}$

55. Ibid, p. 269.

56. Joseph C. Liow, Piety and Politics: Islamism in Contemporary Malaysia (New York: Oxford University Press, 2009), p. I8I.

57. Farish A. Noor, Islam Embedded: The Historical Development of the Pan-Malaysian Islamic Party PAS (195I-2003) (Kuala Lumpur: MSRI, 2004), p. 724. 
Mahathir sought to undermine Islamist opposition by centralizing Islamic discourse and initiating a political Islamization program from above. PAS, however, rejected UMNO's Islamization as hypocritical. The question of how Islamic law should be implemented became a key topic in Malay political debates. The UMNO government has always rejected PAS's calls for a type of Islamic penal code (hududlqisas) — such as is now enforced in Brunei-while the aspiration for hudud laws became a constitutive identity marker for PAS. Despite UMNO's rejection of hudud, Islamist ideological positions have gradually moved from the margins to the mainstream of Malay political discourse across party-political boundaries, ${ }^{58}$ to the discontent of Malaysia's traditionally marginalized non-Muslim population.

Over the last three decades, the UMNO-led government has standardized an antipluralistic brand of Islam while outlawing alternative interpretations as "deviant teachings" - in a manner that closely resembles Brunei's treatment of intra-Muslim diversity outlined above. The UMNO-sponsored Islamic bureaucracy has become an influential, in fact largely untouchable, political player operating in part beyond democratic control. Once gazetted, the state muftis' fatwas become binding and enforceable without going through the usual legislative process. Syariah crimes (jenayah Syariah) are now being prosecuted in several Malaysian states by Islamic enforcement agencies, which conduct various forms of moral policing and intrusions into the private life of Muslims. This pertains for example to the consumption of alcohol, sexual contacts of unmarried couples, homosexual intercourse, "indecent" public behavior, and "falsifications of Islam," all also illegal in Brunei. Religious officers regularly raid hotels and nightclubs across Malaysia, with the notable exception of Kuala Lumpur's tourist areas. In contrast to Brunei, however, Shariah law still applies exclusively to Muslims.

Adherents of "deviant teachings," such as Shi' ite Muslims, are under close surveillance. In one of several instances, more than Ioo Shi'ite Muslims were arrested while celebrating Ashura (the day of ritually commemorating the martyrdom of the third Shi' ite imam, Husayn Ibn Ali) in Gombak in 2010. Shi'ite Islam is formally banned in II of I4 Malaysian states, based on a ruling issued by the Fatwa Committee of the National Council for Islamic Affairs in

58. The vice president of Malaysia's second Malay-dominated opposition party, PKR, told the author that his party generally supports the implementation of Shariah law, although it may disagree with UMNO and PAS over details (interview with Shamsul Iskandar, Kuala Lumpur, March 8, 20IO). 
1996. Similarly, the Ahmadiyyah community was banned from calling itself Muslim and holding Friday prayers at its mosques; the effort included erection by government religious authorities of a signboard at a mosque stating that Ahmadiyyah is "not Muslim." Founded in India in the late I9th century, the Ahmadiyyah defends an apolitical, categorically pacifist interpretation of Islam, summed up in its slogan "love for all, hatred for none." The group is banned and persecuted in several countries, including Malaysia and Brunei, primarily for theological reasons, most notably because its founder, Mirza Ghulam Ahmad, is alleged to be venerated as a prophet after Muhammad. Several Muslims have been sentenced to jail terms and "re-education" in "faith purification centers" (pusat pemurnian akidah baitul iman). In 2009, a self-declared "Malay prophet" who questioned the obligation to do the hajj (pilgrimage to Mecca) was sentenced to Io years' imprisonment, including six months at a religious rehabilitation center. He was found guilty of five charges under the Selangor Syariah Criminal Enactment of 1995, namely sections 7 (False doctrine), 8 (False claim), Io (Insulting or bringing into contempt the religion), I2 (Contempt of religious authorities), and I2 (Opinion contrary to fatwa). In 20II, the first Shariah-based canings for "illicit sex" took place, albeit not yet under Brunei-style hudud legislation. ${ }^{59}$

During a religious event in 20I2, Prime Minister Najib Razak (who took office in 2009) declared that "liberalism" and "pluralism" were "among the biggest threats faced by Muslims in the nation today." ${ }^{\circ 0} \mathrm{He}$ added that "despite universal values being shared by all, matters relating to the aqidah [belief] must be defended and there is no compromise on this." Former Deputy Prime Minister Muhyiddin Yassin (who was dramatically sacked from his position in 2015 by Najib after criticizing the latter's alleged role in a corruption scandal) similarly argued that "people will no longer live harmoniously and through religious guidance if ideologies like liberalism ... are allowed to spread." ${ }^{61}$ Furthermore, pluralism and liberalism would lead to numerous "sins," such as "free mingling of the sexes, same sex marriages,

59. “'Malay Prophet' Sentenced to Io Years Jail, Six Lashes, RMi6,50o Fine," Malaysian Insider (Petaling Jaya, Malaysia), October 22, 2009; "3 Women Caned for Having Illicit Sex," The Star (Petaling Jaya, Malaysia), February I8, 2010.

6o. "PM Warns of Liberalism, Pluralism," New Straits Times (Kuala Lumpur, Malaysia), November 9, 2012.

6I. "DPM: No Harmony if Liberalism and Pluralism Allowed to Spread," Edge Malaysia (Petaling Jaya, Malaysia), October 9, 2012. 
apostasy and deviant behaviour... in the name of individual freedom and human rights." The government's ulama (religious scholars with formal education in Islamic studies) are systematically promulgating the same position. The pro-UMNO cleric Ismail Mina Ahmad, for example, has demonized "religious pluralism" as a "satanic movement that makes the Muslim community become infidel." ${ }^{2}$ The state-Islamic institution JAKIM (Jabatan Kemajuan Islam Malaysia, Department of Islamic Advancement of Malaysia) has recently compared the threat of "liberalism" to that of the Islamic State of Syria/Iraq, and called for jihad against both. At a conference on "de-radicalization," a JAKIM representative added "pluralism" and "LGBT" to the list. ${ }^{63}$

To be sure, a wide range of civil society actors is criticizing the government's Islamic bureaucracy for various reasons, and-unlike in Brunei-it is still possible to openly disagree with the government's religious paternalistic truth claims. Most prominently, Islamic reformist groups such as Sisters in Islam and the Islamic Renaissance Front are tirelessly arguing for tolerance, acknowledgement of plurality, and equal rights within a Shariah-based normative framework. However, they are in an increasingly marginalized position, enjoy very little grass-roots support (unlike the governmental clergy's positions, or those of PAS), and have few (if any) allies left among Malaysia's political elites. Some critics of Malaysia's Islamic governance have faced blasphemy charges, arrests, and various forms of harassment by state and nonstate actors in recent years. ${ }^{64}$

In a much-discussed statement read at the 57th national-level Quran Recital Assembly in 20I4, Prime Minister Najib stated that "Human Rightism" is a "threat" to Islamic values, as its "core beliefs are based on humanism and secularism as well as liberalism." He further stated that "Human Rightism" is "deviationist in that it glorifies the desires of man alone and rejects any value system that encompasses religious norms," while affirming that his

62. Ismail Mina Ahmad, Pluralisme Agama: Satu Gerakan Iblis Memurtadkan Umma [Religious Pluralism: A Satanic Movement that Makes the Muslim Community Become Infidel] (Kuala Lumpur: MUAFAKAT, 20I2); see also "Islamic Scholars: Fight Pluralism Concept," Malaysian Insider, November I8, 2012.

63. "In Friday Sermon, JAKIM Calls for jihad against Liberals, IS," Malay Mail Online (Petaling Jaya, Malaysia), March 20, 2015; "JAKIM: Liberals, Pluralists Have Potential to Be Radicalised," Malaysiakini (Kuala Lumpur, Malaysia), January 26, 2016.

64. See e.g. "Civil Court Throws Out Kassim Ahmad's Bid to Challenge Decision Charging Him with Insulting Islam," Borneo Post (Kuching, Malaysia), July I5, 20I4; "Ulamas Accuse Six of Denigrating Islam," New Straits Times, February 4, 2002. 
government would never tolerate LGBT rights and apostasy, "or deny Muslims their right to be governed by Shariah Courts." Only a few days later, however, the prime minister told the Malaysian Association for the Promotion of Human Rights that, "as Malaysians, we believe in human rights, and subscribe to the philosophy, concepts and norms of the Universal Declaration on Human Rights." ${ }^{65}$ Like the government of Brunei, Najib is using diverse strategies, adjusted to diverse target audiences. In the first statement, addressed to a pious audience at a religious event, he argued within the boundaries of only one normative system-Islamic law-while mobilizing both normativities against each other as incompatible. In his second statement, addressing a secular-oriented human rights organization, he paradoxically affirmed his commitment to the same normativity that he had previously demonized.

Malaysia's government supports the AHRD and UDHR on the symbolic level of international diplomacy. Unlike Brunei, Malaysia also maintains a Human Rights Commission, which even criticized the AHRD for "falling short of expectation," as it permits "restrictions ... on grounds wider than what are accepted internationally." ${ }^{66}$ On the level of de facto enacted domestic policies, however, Malaysia's human rights lobby has no impact whatsoever, in contrast to the government's Islamic bureaucracy. Mainstream Islamist movements, for their part, have also discovered the language of human rights as a political resource. PAS has set up a Bureau for Law and Human Rights, which declared in $201 \mathrm{I}$ that homosexuality is a violation of Article I6 of the UDHR, which protects the fundamental right to come into a marriage as a man and a woman. ${ }^{67}$ In replacing rights with duties, and obscuring the fact that the UDHR is meant to protect sexual self-determination, PAS's approach bears similarities to those illustrated above, namely re-signifying "human rights" with paradoxical meanings to justify religio-political claims that are, strictly speaking, incompatible with fundamental rights stated in the AHRD and UDHR.

65. "PM Says 'Human Rightism, Humanism, Secularism' New Religion Threatening Islam," Bernama (Kuala Lumpur: Malaysia), May I4, 20I4; "Najib Now Says Committed to Human Rights, Days after Denouncing 'Human Rights-Ism'," Malaysian Insider, May I7, 2014.

66. Asia Pacific Forum, "Malaysia: ASEAN Human Rights Declaration Falls Short of Expectation," November 19, 2012, <http://www.asiapacificforum.net/news/malaysia-asean-human-rightsdeclaration-falls-short-of-expectation> accessed August I, 2014.

67. "PAS Youth: LGBT Lifestyle Contravenes Human Rights," Malaysiakini, November 5, $201 \mathrm{I}$. 


\section{ASEAN-IZING SHARIAH LAW? CROSS-BORDER IMPACTS OF BRUNEI'S SHARIAH REFORM}

Parallel to a regional approach to the protection of human rights, transnational networks for the promotion of Islamic law are being forged. On the initiative of Brunei's chief Islamic judge, an ASEAN network of cooperation for Shariah courts was formed in 20I3.$^{68}$ It comprises representatives of Islamic courts from Indonesia, Malaysia, the Philippines, Singapore, and Thailand. While it is important to note that this particular network is not concerned with an Islamic penal code, it is significant that Sultan Hassanal Bolkiah and State Mufti Awang Abdul Aziz Juned have expressed their hope that Brunei's SPCO 20I3 would become an "example for the rest of Southeast Asia" to follow. ${ }^{69}$

In the preparation for SPCO 20I3, Brunei authorities consulted with Islamic institutions that have experience with Islamic criminal law, including in Saudi Arabia, Aceh Province (Indonesia), Pakistan, and Malaysia. ${ }^{70}$ The government of Brunei has praised Saudi Arabia as a leading role model for a "successful" implementation. ${ }^{71}$ Conversely, Middle Eastern countries have lauded Brunei's legal reform. The Deputy Speaker of Kuwait's National Assembly, for example, stated that Brunei's Islamization policies "could potentially lead to another strengthening of the bilateral ties with Kuwait." ${ }^{2}$ Malaysia's PAS published an open letter in 20I3, in which its president, Abdul Hadi Awang, expressed his support for Brunei's implementation of an Islamic penal code.

A number of Malaysian politicians and ulama have since described Brunei as a role model, and discussed how a similar reform could be realized in

68. "Asean Network of Cooperation for Syariah Courts Takes Shape," Borneo Bulletin, September I4, 2013 .

69. "Syariah Law Critics Do Not Understand Islam: Mufti," Brunei Times, January 4, 2014.

70. "Enforcement of Islamic Law in Stages," Brunei Times, March 13, 2013. In one of his television sermons in 20I4, Brunei's state mufti stated that implementing Islamic law would not only bring "blessings" (keberkatan), including material wealth, security, and the absence of natural disasters, but also make Muslims abroad consider Brunei the "star of the East" (bintang timur)—Kuliah Bersama Mufti Kerajaan [Lecture with the State Mufti], RTBI, September 2014.

71. For example, a delegation of 18 members from Brunei's Ministry of Religious Affairs visited Saudi Arabia to "learn" from its Islamic criminal law implementation and to strengthen bilateral cooperation, "especially on the Syariah Penal Code"- "Brunei Delegation Discusses Syariah Implementation with Saudi Officials," Brunei Times, February II, 20I4. See also "Saudi Arabia May Help Brunei Train Syariah Judges, Other Judicial Officials," Brunei Times, May 3, 2014.

72. "Kuwait Supports Brunei's Syariah Law Implementation," Brunei Times, June 7, 2014. 
Malaysia. In December 20I3 the sultan of the PAS-controlled Malaysian state of Kelantan made an official visit to Brunei, followed soon after by Kelantan's chief minister and a state government delegation. Kelantan's sultan, chief minister and state mufti unanimously emphasized their admiration of Brunei's "courage" and declared their intention to "learn" from its Shariah legislation. ${ }^{73}$ Shortly afterward, a delegation from the Malaysian state of Selangor's Fatwa Committee visited Brunei. Its head declared that "every Muslim [in Brunei] must think positively" about the SPCO 2013 and "help" implement it: "If he hears [of] any individual that does not approve... the implementation of Syariah law then he should educate the individual." 74

The delegation leader also shared his institution's experience with fighting apostasy, and explained to his Bruneian counterparts that Malaysia's "Syariah courts would not allow individuals to murtad [become apostates], therefore they send them for counseling. There have been many successful cases... when the individuals change their mind after counseling."

While Brunei's legal reform has triggered heated debates about implementing hudud in Malaysia, many pious Malays are now wondering why Malaysia is still refusing to enforce "God's law," resulting in growing anxieties among Malaysia's non-Muslim and less Islamist-oriented Muslim populations. One of Malaysia's most popular religious scholars, Ustaz Azhar Idrus, has called on Malaysian politicians to follow Brunei's model. ${ }^{75}$ Most recently, a delegation from Malaysia's Ministry of Religious Affairs, headed by the minister himself, visited Brunei in September 2014 to learn about "the implementation of various Islamic initiatives, which include the Syariah Penal Code Order 2013." ${ }^{\prime 6}$

73. "Kelantan to Learn from Bruneian Syariah Penal Code," Brunei Times, December 26, 2013; "Abdul Hadi Awang Tahniah dan Syabas kepada Negara Brunei Darussalam" [Abdul Hadi Awang Congratulates and Lauds Brunei Darussalam], Harakah Daily (Kuala Lumpur, Malaysia), November 2I, 2013; "Umno MP Says Party Will Support PAS's Hudud Plan in Kelantan," Malaysian Insider, November 16, 20I3; "Masa Sesuai Laksana Hudud" [The Time is Right to Implement Hudud], Sinar Harian (Shah Alam, Malaysia), January I2, 20I4; "Hudud: Veteran UMNO, KMPP Sokong Pas" [Hudud: UMNO, KMPP Veterans Support PAS], Utusan Online (Kuala Lumpur, Malaysia), April I3, 20I4; "Hudud: Bersediakah Kita?" [Hudud: Are We Ready?] Sinar Harian (Shah Alam, Malaysia), May 4, 2014.

74. "Call for All Muslims to Help Educate Others on Syariah law," Brunei Times, May 23, 2014.

75. "Komen Ustaz Azhar Idrus Sultan Brunei Jalankan Hudud" [Ustaz Azhar Idrus's Comment on Brunei's Sultan Implementing Hudud], YouTube, January I5, 20I4, <http://www.youtube.com/ watch? $=\_$pKNy39EeB8 $>$accessed August I, 2014 .

76. "Regional Efforts Needed to Promote Islamic Causes," Brunei Times, September 9, 2014. 
Encouraged by the Brunei-inspired wave of intensified pro-hudud sentiment, the Kelantan legislative assembly passed its own hudud act in March 20I5, notably also operating with a model of implementation in "stages." The Shariah Criminal Code II 1993 (Amendment 20I5) follows up on attempts to implement hudud in Kelantan in the 1990s, which were stopped by the central government's intervention. However, parts of the UMNO-led government have signaled that they might now accept the law, or parts of it, although this might also have been a temporal party-political maneuver. In the Kelantan State Assembly, all I2 UMNO delegates voted for the new code.

Brunei's decision to forge ahead with its legal Islamization policies may therefore raise the stakes in the region, particularly vis-à-vis the dynamics of "piety-trumping" between competing Muslim political groups in Malaysia. ${ }^{77}$ In Indonesia, unlike Malaysia, calls for implementing hudud laws do not play a central role in mainstream political discourse, and they have not become identity markers for large Muslim organizations in any comparable manner. However, some Indonesian voices, particularly from the more radical spectrum, have enthusiastically lauded Brunei's legal reform. ${ }^{78}$

\section{CONCLUSION}

This article is not intended to question the theoretical possibility of multiple justificatory grounds for human rights. Certainly, adherents of differing normative traditions may endorse the same conception of universally acceptable human rights and justify it in their own terms. In the case of (re)interpreting Islamic law, this can be observed in the courageous writings of several liberal Muslim thinkers across the globe, including Southeast Asia (but excluding Brunei). However, when it comes to the realities of contemporary Islamic governance and public religious discourse in Brunei and Malaysia, the idea of plural justifications of human rights faces serious obstacles. In both countries, hardline Islamist ideals of antipluralistic state organization have moved from

77. Liow, Piety and Politics, p. I3; cf. Human Rights Resource Centre, Keeping the Faith, pp. $53 \mathrm{ff}$.

78. See for example a "news" report on the Indonesian website Arrahmah.com, which is locally infamous for its sympathies for and personal proximity with jihadi terrorist organizations, and managed by Muhammad Jibril Abdul Rahman, the son of a former Jema'ah Islamiyah member: "Jawapan Sultan Brunei atas Kecaman Barat terhadap Penerapan Syari'ah Islam" [Response of the Sultan of Brunei to Western Criticism over the Application of Islamic Law], Arrahmah, May II, 20I4, $<$ http://www.arrahmah.id/news/20I4/o5/rI/jawaban-sultan-brunei-atas-kecaman-barat-terhadappenerapan-syariah-islam.html> accessed April 20, 2016. 
the margins to the mainstream. This has developed to the point where no Muslim political leader or governmental Islamic scholar openly defends a brand of Islam that acknowledges the right to freedom of thought, conscience, or religion-or accepts an equal legal and social status without distinction of gender or religion. Most obviously, this tendency is manifested in numerous ways: the increasing enforcement of Islamic criminal law, introduction of corporal punishment for religious offenses, systematic discrimination against followers of alternative interpretations of Islam, imprisonment of "heretics," forced "religious counseling," moral policing, and the empowerment of religious bureaucracies and enforcement agencies. All of these phenomena and their underlying discursive trends can, to varying degrees, be observed in both countries, where an antipluralistic brand of Shariah law presently characterizes the implementation of Islamic policies.

Although Islamic policymakers in Brunei and Malaysia are in some instances referring to Islamic law and human rights simultaneously, which may be read as an attempt at bridging the two, the paradoxical ways this is done impede the project of a transdoctrinal, plural justification of human rights and subsequent universal acceptance of human rights. To be sure, the statements of the sultan of Brunei and his state mufti do indicate that from their perspective, universal human rights are supported by their own, Shariah-based doctrines. However, some of the specific meanings they ascribe to "human rights" are transforming the signifier's contents to an extent that makes a substantially "unifying conclusion" practically impossible. That does not mean that Shariah law and the UDHR- or AHRD-based conceptions of human rights are incompatible per se, or that there would be nothing in human rights treaties on which there would be consensus. But the mainstream discursive construction of Shariah law, as it is now hegemonic in Brunei and Malaysia, and its power-political embeddedness and institutionalization, give very little reason to believe that a unifying conclusion on matters pertaining to religious freedom might be supported by Islamic policymakers in the foreseeable future- even less so as they at least occasionally denounce "human rights" in populist discourses of proclaimed cultural identity difference vis-à-vis "the West." As the realities of Shariah politics in both countries illustrate, there is consensus neither on the philosophical foundations of human rights nor on the unconditional validity of human rights declarations and treaties.

The simultaneous upholding of international human rights declarations that protect religious freedom on the one hand, and of a normatively 
incompatible interpretation of Shariah law on the other-and the diverse modes of navigating between the two in political rhetoric-illustrate the flexible ways in which social actors generally position themselves in between multiple normativities. However, in the context of Islamic governance in Brunei and Malaysia, this flexibility has clear-cut boundaries, insofar as an uncompromising insistence on the normative superiority of Islamic law effectively defines the contents and real-life consequences of domestic policies, whereas the proclaimed commitment to human rights declarations remains largely limited to a symbolic level of international diplomacy. 